Dorirua East is currently undergoing a state-led gentrification project under the guise of 'regeneration'. Residents of Porirua East saw what happened in other areas like Glen Innes and, anticipating this threat, formed Housing Action Porirua (HAP). Contextualising the Porirua redevelopment within a broader history of colonisation and racist exploitation, we outline the redevelopment to date and give a history of displacement and dispossession of iwi, and later migrant workers, in Porirua. We chart HAP's struggle for the community and outline the group's five demands for a true regeneration that honours te Tiriti o Waitangi, protects the earth, and ensures that no whānau are displaced. We urge that the expansion of state housing is a critical demand for working-class communities which, if guided by te Tiriti, also has the potential to concretely restore mana and rangatiratanga to tangata whenua. 


\section{Dispossession and Gentrification in the Porirua Redevelopment}

\section{JASMINE TAANKINK \& HUGO ROBINSON}

In Aotearoa New Zealand, housing is no longer considered a right. We live wherever we can afford to, even if that does not suit our needs or makes us sick. State housing and its tenants have been neglected and demonised, while the pockets of landlords have continued to be lined with tax from the working classes under the guise of 'social welfare'. This is a problematic system that supplements rent payments rather than addressing the root of the problem in which many people are barred from having secure shelter. Workingclass tenants are contributing to property investment every week without seeing any return. Houses that are physically deteriorating are rapidly increasing in price, locking the working class out of home ownership. While other models, like low deposits, have been offered to us, if the price is too high then all whānau have to gain is intergenerational debt. All this is the result of long-standing colonial-capitalist processes that commodify land and life and actively work to destroy other ways of living where everyone has a home and the earth is protected.

The housing crisis has been aggravated by successive governments who believe state housing to be at odds with economic development. By and large, it is business as usual for the current Labour-led government. The government looks to appease its traditional working-class support while also 
affirming its commitment to corporatisation and privatisation. However, there are also novel elements in play, such as the establishment of Kāinga Ora, a new ministry comprising Housing New Zealand, its development subsidiary Homes Land Community (HLC, originally Hobsonville Land Corporation), and Kiwibuild, whose mandate has 'extended beyond the provision of state housing to include transitional, affordable and market housing. ${ }^{1}$ Kāinga Ora is a new development that exemplifies how the state cloaks ongoing colonialism in 'post treaty-settlement' partnership. As will be touched on later, this 'partnership' bears little semblance to a truly just, equitable, and mutual Tiriti relationship.

Housing Action Porirua (HAP) is a resident-run group that was established at the beginning of 2019 in response to the Porirua East community's concerns around the Porirua redevelopment. We met weekly for most of that year to discuss the plans as they unfolded and to spread awareness of how the plans might impact people. Though small, HAP consists of people who are deeply engaged with their communities. We have members working in local iwi health, in unions, in childcare, and libraries; we have people who are active in Pasifika associations, in neighbourhood committees, and disability-rights groups. It has been run mainly by wāhine and is focussed on preserving the ways of life that communities have built in Porirua East for over half a century.

Throughout this article 'we' is mostly used interchangeably to refer to our group and the people of Porirua East. However, when talking about the larger political context, 'we' refers more broadly to HAP, the people of Porirua East, and anyone else who believes in the kaupapa of expanding state housing. The aim of this piece is to show what is happening in Porirua East so that readers will inquire further into the housing situation right now, the forces working to degrade it, and the groups looking to protect it. Ultimately, we do so to invite solidarity with our mahi, provided the community's needs and dreams are prioritised.

This article discusses the Porirua redevelopment, initiated in 2018

1 New Zealand Government, 'Briefing for the Incoming Minister of Housing,' Wellington, Housing New Zealand, 2019. 
by Housing New Zealand, HLC, and Kiwibuild (now run by Kāinga Ora). Though plans have changed over the past two years, at present the redevelopment, which is focussed in Porirua East, will see about 2,000 state houses upgraded, the construction of about 2,000 affordable and marketpriced homes (this figure originally included Kiwibuild homes), and the construction of up to 150 additional state houses in Porirua. We argue that this is a state-led gentrification project that is strikingly similar in planning and rhetoric to the Glen Innes regeneration. ${ }^{2}$ In both cases, the renewal of fewer state houses will be funded by freeing up most of the land for private development and displacing those communities to make way for private housing sold predominately to the white middle class. ${ }^{3}$ Even the government's boldest promises for the redevelopment barely make a dent in the state-housing waiting list, which does not include the many people who are currently living in cars, garages, and crowded living rooms. ${ }^{4}$

The rest of the article proceeds as follows. To contextualise the current situation in Porirua, the first two sections chart the history of state housing and land in Aotearoa New Zealand. There are three reasons for introducing this longer narrative. First, it is necessary to underline the depth and importance of the land and its housing for mana whenua and all the different communities that have come to build homes there. Second, understanding the dispossession experienced by Ngāti Toa Rangatira is crucial for understanding how the Crown fails to right those injustices by continuing to include the iwi on a provisional basis—not substantively

2 In this article, gentrification is used to describe the process of predominantly working-class neighbourhoods being taken over by wealthier people. In Porirua, this has a strong racial component and is facilitated by the state.

3 Vanessa Cole, 'We Shall Not Be Moved': Community Displacement and Dissensus in Glen Innes, Tamaki Makaurau (Masters thesis, University of Auckland, 2015).

4 Currently, the waitlist for social housing is at a record high of 16,309. See New Zealand Government, 'Public Quarterly Housing Report,' Wellington, New Zealand Government, March 2020. The estimated number of homeless people is 41,000 . See New Zealand Government, 'Cabinet Paper Preventing and Reducing Homelessness in New Zealand,' Wellington, New Zealand Government, September 2020. 
moving toward the regeneration of their mana and rangatiratanga. ${ }^{5}$ Third, this longer narrative demonstrates that an analysis of state housing requires an analysis of how the land beneath it was acquired. In Aotearoa New Zealand, this has been a brutal colonial process—regardless of the context of even the most 'peaceful' land sales.

The third section gives a brief overview of the Porirua regeneration so far, and charts HAP's struggle to resist the displacement of the communities of state tenants and private renters alike. To this end, our group formulated five demands for the regeneration: (1) make houses and urban spaces more accessible; (2) implement sustainable urban-planning and building practices; (3) implement community control of the project; (4) commit to building more state housing; and (5) ensure that all whānau who want to stay can. These demands are practical and speak to the immediate reality of our situation. Our individual and collective dreams for Porirua, for Aotearoa, for our worlds, are, of course, much broader. While we would like to believe that the regeneration could help existing communities to flourish, the bottom line is that there has been no promise that whānau will not be pushed out. This fact guides our analysis and prompts urgent action.

In the final section, we emphasise our commitment to te Tiriti o Waitangi and the affirmation of the mana and rangatiratanga of Ngāti Toa Rangatira. Here, we question how the mana and rangatiratanga of hapu and iwi could possibly be affirmed (if at all) in such a redevelopment project. While we will not speak to it in great length here, it is a given for us that the struggle to protect and expand state-housing communities is necessarily connected to a larger project of decolonisation and re-indigenisation. The Porirua regeneration demonstrates the urgency of this project, especially as we are ushered into a 'post-settlement era' where privatisation further hinders the rightful return of stolen land to Māori by the state.

5 When we talk about dispossession, we refer to historical and ongoing processes of colonisation. This includes the theft of land, the imposition of Crown sovereignty and common law, and the desecration of tikanga, mātauranga, and reo; in short, the attempted denial of mana motuhake and rangatiratanga. 


\section{History of land in Porirua-dispossession}

A history of state housing is a history of the land and of who has the power to organise social life on that land. In Porirua, as anywhere else in Aotearoa New Zealand, the power and resources that have been used by the state, for the benefit of Pākehā, have been secured by dispossessing hapu and iwi of land and undermining their mana. ${ }^{6}$ This dispossession has continued through to the current era, with the state continuing to hold, sell, and desecrate stolen land for the benefit of the colonisers. Such sales are prompted by the ever-increasing market-value of land and the belief that it will be best used in resolving the country's housing crisis if transferred into private hands. Land and power are at the root of the problem: the plight of state housing reflects the sometimes hidden, sometimes explicit, but always brutal methods through which capitalism and colonialism are maintained. A history of land occupation in Porirua shows very clearly whose lives are deemed disposable and whose land will be desecrated by the state in the interests of others.

Porirua has been an important home for Māori hapū and iwi for over 600 years. Kupe is thought to be the first to arrive at Paremata Point. He did not settle there, but named sites of significance while passing through, such as Te Mana o Kupe ki Aotearoa (Mana Island) and Komanga-Rautawhiri, and left his anchor stone, Te Punga o Matahourua, at Whitireia. ${ }^{7}$ The rohe has been inhabited by various hapū and iwi throughout the centuries, including Ngāti Ira and Ngāi Tara, and currently Ngāti Toa Rangatira. During this time, the harbour was an abundant source of food as well as a central place of cultural and spiritual health. Porirua is a place with a rich cultural and material history, a beautiful and bountiful land to live in.

In the early 1800 s, settlers were already competing with one another for the purchase of title over Ngāti Toa Rangatira lands. As Elsdon Best records (untrustworthy as he is), at least five different parties claimed

6 Margaret Mutu, “"To Honour the Treaty, We Must First Settle Colonisation” (Moana Jackson 2015): The Long Road from Colonial Devastation to Balance, Peace and Harmony,' Journal of the Royal Society of New Zealand 49, no. 1 (2019): 4-18.

7 Oral history. 
ownership over Kāpiti Island and eight claimed Porirua. ${ }^{8}$ All claims related to different portions of land — up to 23,000 acres—and were 'bought' for different amounts from various Māori groups or individuals. However, as elsewhere in Aotearoa, the New Zealand Company was the most prominent in making fraudulent and deceptive claims to vast areas of land for settlement. In 1839, Edward Jerningham Wakefield claimed he had purchased 20 million acres of Ngāti Toa Rangatira land in the top of Te Wai Pounamu and the mouth of Te Ika-a-Māui (including land of other hapū and iwi). Unsurprisingly, the oral translation of the transaction did not convey this.?

During the 1840 s, tensions were rising as settler surveyors, primarily of the New Zealand Company, attempted to map out urban settlements on Ngāti Toa Rangatira land. ${ }^{10}$ These tensions resulted in resistance, such as at Waitara, where mana whenua used non-violent protest to interrupt the surveying of land that was not owned by settlers. ${ }^{11}$ Conflict also broke out, like in Wairau where 22 Pākehā and four Māori were killed in a skirmish when Ngāti Toa Rangatira tried to protect their territory from these acts of invasion. Closer to Porirua, at Tuamarina in the Hutt Valley, there was a similar conflict. This time, as elsewhere, the Crown came to the aid of the New Zealand Company and local settlers against Māori. Around 1845, Te Rangihaeata and Te Rauparaha were allied against the Crown's violent attempts to take their land and cease their authority. In 1846, Governor Grey ordered that Te Rauparaha be kidnapped and detained without trial

8 Elsdon Best, 'Porirua - And They Who Settled It,' Canterbury Times, March 1914, retrieved from http://www.tawahistory.org.nz/projects/best_article_porirua. html. Best was the most prominent of early colonial anthropologists studying Māori. His descriptions are, like all colonising anthropologists, coloured by his own ethics and racist vision of the world.

9 New Zealand Government, 'Ngāti Toa Rangatira Settlement Claims Act 2014,' Wellington, New Zealand Government, 2014, 13-14.

10 Cathy Marr, 'Rangahaua Whānui National: Theme Public Work Takings of Māori Land, 1840-1981,' Wellington, Watiangi Tribunal Rangahaua Whānui Series, 1997, 32.

11 Giselle Byrnes, Boundary-Markers, Land Surveying and the Colonisation of New Zealand (Wellington: BWB, 2003), 108-109. 
for 18 months for the violence, despite Te Rauparaha having played no direct part in the conflict. ${ }^{12}$ Meanwhile, a militia of colonisers and Māori (whose strategic interests may have aligned against Ngāti Toa Rangatira rather than with the Crown) attacked and forced Te Rangihaeata and his supporters to flee to Ōtaki. Grey then forced through the deeds to Wairau and Porirua in transaction with remaining Ngāti Toa Rangatira who were hoping for Te Rauparaha's release. Through such measures, Ngāti Toa Rangatira were violently coerced into ceding most of their land.

Whitireia Peninsula was part of the 16 sections that Ngāti Toa Rangatira did retain. This was gifted to the Anglican Church in 1848 with the express agreement that a school would be built. ${ }^{13}$ The school was not built, and Wiremu Te Kakakura Parata took to the courts in 1877 to retrieve the land. We now know this case as the famous Wi Parata $v$ Bishop of Wellington in which Chief Judge James Prendergast stated that the Treaty was a 'simple nullity. ${ }^{14}$ Not only did this reveal the context of the law's position on te Tiriti at the time, Boast suggests it was also tied to contention around education for Māori. ${ }^{15}$ Ngāti Toa Rangatira were pushing for education that empowered their people, rather than purposefully funnelling them into low-valued labour. In that context, the dismissal of their rangatiratanga in the courts can be seen as a formal verification of the dismissal of their mana on the ground.

In the years 1948 to 1960 , the Crown took 500 acres of prime land in Takapūwāhia and other areas in eastern Porirua under the Public Works

12 NZG, 'Ngāti Toa Rangatira Settlement,' 17.

13 Grant Morris, 'James Predergast and the Treaty of Waitangi: Judicial Attitudes to the Treaty During the Latter Half of the Nineteenth Century,' Victoria University Law Review 35, no. 1 (2004): 120.

14 'Wi Parata v The Bishop of Wellington,' Supreme Court Wellington, 1877, in New Zealand Jurist, 72.

15 Richard Boast, "So Long Lying Idle Without a School": Wi Parata, Wallis and Whitireia, 1848-2008,' New Zealand Journal of Public and International Law 7, no. 1 (2009): 237-272. 
Act for general and state housing. ${ }^{16}$ The areas for state housing were simply taken, for the benefit of others, without regard to the people living there; what we see today is a repeat of this process. Some of the land was never developed, and Ngāti Toa Rangatira have since had to buy it back from the Crown. ${ }^{17}$ Moreover, the land was developed for settlement with no respect for the environment, severely degrading Te Awarua o Porirua, including the destruction of mahinga mātaitai. ${ }^{18}$ The desecration of the coastal environment has continued through to the present day with the intensification of suburban space without adequate planning or sustainable building practices.

Understanding the above history is crucial for comprehending what lies behind contemporary discussions of state housing in the area. Important here is an appreciation of the means by which mana whenua lost their power and wealth, and just how deep that loss has been. It is a sustained dispossession, which, like elsewhere in the world, was essential to establishing colonial capitalism in Aotearoa. Further, colonial capitalism maintains itself through ongoing dispossession and exploitation. ${ }^{19}$

What must be made clear is that the current regime of dispossession which manifests in the decline of state housing is part of the same regime that was established by colonisers 150 years ago. 'Invasion', as Patrick Wolfe's maxim goes, 'is a structure, not an event'. ${ }^{20}$ Gentrification, though perhaps a new strategy for money-making, is an extension of that structure, and while the expansion of state housing is a good and necessary thing, we should pay attention to how it features in colonial dispossession. This deeper history of loss provides the context for the discussion of gentrification in the next section.

16 Marr, 'Rangahaua Whanui National,' 186; NZG, 'Ngāti Toa Rangatira Settlement Claims Act 2014,' 17.

17 NZG, 'Ngāti Toa Rangatira Settlement,' 122-126.

18 NZG, 'Ngāti Toa Rangatira Settlement,' 17.

19 Robin Kelley, 'The Rest of Us: Rethinking Settler and Native,' American Quarterly 69, no. 2 (2017): 274; David Harvey, The New Imperialism (Oxford: Oxford University Press, 2003), 169-171.

20 Patrick Wolfe, 'Nation and MiscegeNation: Discursive Continuity in the Post-Mabo Era,' Social Analysis no. 36 (1994): 96. 


\section{State housing in Porirua-gentrification}

The plight of state housing tells many important stories. Primarily, it illustrates the different economic models pursued by New Zealand governments, especially when responding to major political-economic events like war and recession. In Porirua, the history of state housing is tied to the ongoing maintenance of colonial power and wealth creation through dispossession. State housing also tells a story of immigration, displacement, and the inseparability of racism from the everyday workings of capitalism. Here, gentrification entails the privatisation of land dispossessed from mana whenua as well as the further displacement and exploitation of working people. ${ }^{21}$

In the Great Depression, Aotearoa New Zealand was suffering widespread poverty and an acute housing shortage. In response, the government conducted a mass housing survey in 1935, which found that there was a dire need for state housing. ${ }^{22}$ Porirua was identified-among four potential sites - as a suitable location for state housing due to existing infrastructure, favourable terrain, and because land prices were the cheapest in the Wellington region. State housing in Porirua was built as a 'dormitory' for workers going into Wellington, just as Glen Innes was a 'dormitory' for Auckland workers. ${ }^{23}$ In 1945, the population of Porirua was 5,000; by 1965 it had grown to $21,000 .{ }^{24}$ At its peak in 1970 , Porirua had the highest concentration of state housing in Aotearoa New Zealand, with 70 percent of the population living in public dwellings in the east and west.

While state housing was built for working populations, it had far fewer

21 For more on state housing in Aotearoa New Zealand, see Vanessa Cole, this issue.

22 Chantal Mawer, 'Historical Snapshot of Porirua,' 2016, http://www.idcities. co.nz/resources/Porirua\%20Historical\%20Snapshot.pdf

23 Kathryn Scott, Angela Shaw, and Christina Bava, 'Social Equity and Social Housing: Densification in Glen Innes, New Zealand: A Political Ecology Approach,' in Urban Pollution: Cultural Meanings, Social Practices, eds. Eveline Dürr and Rivke Jaffe (New York: Berghahn Books, 2011), 182.

24 Patrick Mullins and J. Robb, 'Residents' Assessment of a Social Housing Scheme,' Environment and Behaviour 9, no. 4 (1977): 583. 
restrictions on eligibility than it does now. ${ }^{25}$ It was not just reserved for the poorest. It is clear, though, that Pākehā were the primary beneficiaries of state housing. For instance, when the national housing survey was conducted, a separate survey was conducted for Màori. The results identified significant levels of inequality for Māori, leading the government to pass the Native Housing Act 1935 for the purpose of subsidising tangata whenua to build, buy, or maintain housing. ${ }^{26}$ However, due to the discretionary powers of the board in charge of allocating funds, as well as the strict conditions for eligibility, most Māori were unable to receive support. ${ }^{27}$ Indeed, while they were not formally excluded from state housing in law, Māori were effectively shut out until the late 1950 s due to systemic racism. ${ }^{28}$

In 1966, Porirua was comprised of 87 percent Pākehā, 9 percent Māori, and 4 percent Pasifika, with state housing accommodating both modestly educated workers as well as government employees. ${ }^{29}$ However, the demographic profile of Porirua changed significantly once Māori and tagata o le moana access to state housing improved. Much of the industry in Newtown, a relatively central Wellington suburb, moved out to Porirua where land was cheaper. This led to a significant increase of Pasifika peoples, both from within Aotearoa New Zealand and overseas, as well as maata waka-some were moving with their existing jobs, others were searching for new work. ${ }^{30}$ With this shift in demographic, the vilification of statehousing tenants, which had originally been classist attacks on Pākehā, took on a more racial character. ${ }^{31}$ This was evident in the idea that concentrations of 'social deprivation' (read brown, working-class communities) caused

25 Cole, We Shall Not Be Moved, 40-41.

26 Alice Mills et al, Meeting the Housing Needs of Vulnerable Populations in New Zealand (Auckland: University of Auckland Press, 2015), 11.

27 Mills et al, Meeting the Housing Needs, 11.

28 Mills et al, Meeting the Housing Needs, 11.

29 Mullins and Robb, 'Residents' Assessment of a Social Housing Scheme,' 584.

30 Damon Salesa, Island Time: New Zealand's Pacific Futures (Wellington: BWB, 2014), 33. Maata waka, also called urban Māori, refers to Māori who are in the rohe of another hapū.

31 Cole, We Shall Not Be Moved, 41. 
negative social outcomes, rather than the systemic racism which pushes those communities into low-paid jobs and unemployment, and as a consequence, housing insecurity.

Despite this, Porirua East was built and strengthened throughout this period by the life-giving creativity of people making new homes. Even as state support became more restrictive during the neoliberal restructuring of the 1980s, and the quality and quantity of state housing was in decline, the heart of Porirua East, Waitangirua and Cannons Creek, was growing. However, by the 1990s industry began to vacate Porirua as it searched for cheaper labour elsewhere, degrading the economic base around which this now strong community was built. This flight of capital and jobs from Porirua had nothing to do with state housing, and yet the government argues that majority-state-housing communities cause 'negative spill-over effects by concentrating economic disadvantage', and that 'investment that de-concentrates public housing can have positive spill-over effects'. ${ }^{32}$ Rather than identifying the issue as the systematic oppression of working communities, the argument for de-concentration identifies the communities themselves as the issue. This opens up the justification for a new wave of state-led gentrification to be initiated, where wealthier people move outward to buy homes in affordable areas-notably, former state-housing areas in the Wellington region like Naenae, Pomare, and Lower Hutt.

In short, we can plot the concentration and displacement of Māori and tagata o le moana workers alongside the changes in production around the country. Newtown in Wellington, like Ponsonby in Auckland, was a site of industrial manufacturing in the early 1950s, where Māori and tagata o le moana workers clustered. ${ }^{33}$ Workers then moved outward from both areas to follow the jobs that were established further out of the cities- where statehousing communities were built-in Glen Innes and Porirua respectively. This was accompanied, and indeed facilitated by, the gentrification of

32 New Zealand Government, 'Eastern Porirua Regeneration Case,' unreleased, 16.

33 Salesa, Island Time, 33. 
Ponsonby and Newtown as living costs increased in the centres. ${ }^{34}$

Over the past 40 years, Wellington has grown as a centre of information, government, and finance capital. The middle classes compete with landlords for home ownership and compete with students and other workers for rentals. Home ownership for many of these people is out of the question in Wellington City, but not in Porirua. As stated by Kāinga Ora in the Porirua Business Case:

There is now significant underlying unmet demand for housing in the Wellington Region, particularly for smaller and more affordable dwellings. Analysis by CBRE [Coldwell Banker Richard Ellis] indicates that there is already existing demand for over 1,000 terraced dwellings around $\$ 500,000$ from households across Wellington that could be met specifically by housing in eastern Porirua. ${ }^{35}$

These are prices that, while affordable for some in Wellington, are well above the means of the people in Porirua East. The more affluent workers are therefore prioritised because they mean profit for developers, and this in turn funds the renewal of state housing. Such unaffordability of housing marks the turning point for a new wave of gentrification to begin.

As is evident in the history of housing and land in Porirua, and Aotearoa New Zealand generally, dispossession and displacement will be key features of any regeneration. This is because they are central to colonial domination and capital accumulation, as argued above. Dispossession is profitable and it can be justified through market imperatives and racial narratives. This process is neatly captured in Kāinga Ora's averseness to 'concentrations of social deprivation' and the public scare-mongering around methamphetamine use, crime, and poor health outcomes.

If it were really the case that such a regeneration was for the people of eastern Porirua, there would not be such an urgency to privatise what little is left of public land. If the cause and gravity of this ongoing crisis were

34 Laurence Murphy, 'Third-Wave Gentrification in New Zealand: The Case of Auckland,' Urban Studies 45, no. 12 (2008): 2522.

35 NZG, 'Eastern Porirua Regeneration Case,' 18 [emphasis added]. 
truly registered by those in power-let alone the simple fact that everyone deserves to be housed - every effort would be made to expand state housing. But this is not the case, and so it is up to those who live in the community, and those who will stand in solidarity, to mobilise to disrupt what we are otherwise told is an inevitability. It is up to us to demand that the needs and aspirations of the people of the Porirua East guide the redevelopment. ${ }^{36}$

\section{Porirua redevelopment and the formation of Housing Action Porirua}

When seeing the announcement for a regeneration that promised no major increase in state housing, while also making way for private housing, it became quite clear that the 'regeneration' did not have the people of Porirua East's interests in mind. This became clearer as the groundwork was being done by HLC (now Kāinga Ora) of building rapport with communities of the east, which involved making more promises backed with fewer guarantees. The plan, which was announced in November 2018 at Russell School in Cannons Creek, has been described by the government as 'the biggest and most ambitious regeneration since Eastern Porirua was built'. ${ }^{37}$ In reality, it is just another Glen Innes-style development with no real ambition at all. ${ }^{38}$

One of the issues HAP have encountered is inconsistency around how many homes, and of what kind, will be built. When first announced in 2018, the plan was to renovate or rebuild around 2,900 Housing New Zealand homes; build 2,000 affordable Kiwibuild and market-priced houses in Porirua East, with priority given to local residents; and to add 150 new homes to the existing state-housing stock. ${ }^{39}$ Over time these numbers have become less and less impressive. As calculated by Kiwibuild,

36 On community engagement in Porirua, see Elyjana Roach, this issue.

37 New Zealand Government, 'Porirua regeneration means thousands of new homes,' Beehive, 1 November 2018.

38 See Cole, 'A Case for Universal State Housing,' this issue.

39 NZG, 'Porirua regeneration means thousands of new homes.' 
'affordable' means houses capped at $\$ 550,000$, which is well out of the means of most people living in Porirua East. ${ }^{40}$ Such prices would saddle those whānau with massive, intergenerational debt. Second, the promise to build 150 additional state homes has changed to 'up to' 150 state homes, which are not necessarily to be built in the same location. ${ }^{41}$ To say that the project is ambitious ignores the fact that even if 150 additional state homes were to be built in 2020 this would not be enough to house those on the waiting list in Porirua, which is currently at 277 applicants. ${ }^{42}$ For a 25 -year plan, the numbers are completely inadequate.

With this redevelopment, the government has partnered with Porirua City Council and Ngāti Toa Rangatira, whose role is significant because it 'made the regeneration possible'. ${ }^{43}$ This is because Ngāti Toa Rangatira were granted Rights of First Refusal (RFR) over all the public housing in the east in their settlement deed. The deal made for the regeneration is that Ngāti Toa Rangatira would waive these RFR in return for becoming responsible for upgrading and maintaining about 900 Housing New Zealand properties on the west side for 25 years. This has been heralded by the Deputy Leader of the Labour Party Kelvin Davis as an important first partnership brokered by Te Arawhiti, his new Māori-Crown Relations portfolio. It is a partnership that represents a new era in Treaty relations and, more insidiously, a new way that the government seeks to enable the privatisation of Crown land. This effort to work alongside Māori is symbolically positive. However, it remains just that, a symbol that is used

40 In 2018, 19.1 percent of Porirua East earned \$50,000 or more per annum, compared with 34.9 percent in Porirua, 37.1 percent in the Greater Wellington Region, and 31.6 percent nationwide. As at 2018, unemployment was at 13.8 percent in Porirua East compared with 7.8 percent in Porirua City, 6.2 percent in the Greater Wellington Region, and 5.8 percent nationwide. Calculated from ID Community, available at: https://profile.idnz.co.nz/porirua/

41 Housing New Zealand Corporation, 'Housing New Zealand welcomes Porirua regeneration plan,' https:/www.hnzc.co.nz/news/latest-news/housing-new-zealand-welcomes-porirua-regeneration-plan/

42 Ministry of Urban Development, 'Housing Register,' https:/www.msd.govt.nz/ about-msd-and-our-work/publications-resources/statistics/housing/

43 NZG, 'Porirua regeneration means thousands of new homes.' 
by the government in its communications with residents and the wider public to signal its commitment to te Tiriti and to consultation. In reality, there is little in the way of the government treating honourably with Ngāti Toa Rangatira. For instance, the government did not provide any resources or infrastructure to ease Ngāti Toa Rangatira into the significant role of managing 900 state homes. ${ }^{44}$

All announcements and subsequent consultations have left out that the houses for purchase will be built on Crown land that will be sold to developers in 'superlots' (sections of land that are far larger than normal and common in large-scale developments). It is only through the experience of others in Tāmaki Makaurau, Pomare, Marfell, and elsewhere that our group knew to look for this. ${ }^{45}$ In addition, securing the business case for the development has given the community some more insight into what the plan is, the spirit it was created in, and what we need to organise around. It has also confirmed for us that residents' concerns for their communities are not being included in any substantive way. Most important for HAP is that the government has not promised that people will be able to return if they wish. Even if the government does promise that people will be able to return, it will not be to the same communities that they had left. Ultimately, it is not just the physical dwellings HAP is fighting to protect, but the communities who call this area home.

HAP has developed five goals and principles that draw on concerns raised by residents. These would, were they to be followed, ensure an equitable regeneration. We introduce each below.

\section{More affordable, healthy state homes}

Similar developments around the country have resulted in a decline in state housing. Places like Pomare have been impacted the most, with 89 state houses demolished to make way for 150 new homes, only 13 percent of

\footnotetext{
44 NZG, 'Eastern Porirua Regeneration Case.'

45 We have taken inspiration and insight from Tāmaki Housing Group and those whānau from Farmers Crescent whose houses were demolished to make way for the Riverside Gardens subdivision.
} 
which are state owned. ${ }^{46} \mathrm{With}$ home ownership a priority for policymakers, public land is sold to developers whose motive for building houses is profit. ${ }^{47}$ Although the plan for Porirua East is framed in the language of wellbeing, the logic that is actually behind it is essentially the same: sell off a certain amount of state-housing land to fund the rebuild of predominantly market-priced homes while simultaneously pushing for community providers to take over provision for those in need. Another key aspect for the policymakers is that the state housing that remains be run as profitably as possible. As the unreleased business case puts it:

The preferred structure is for all revenue from land sales and IRRS [Income Related Rent Subsidy] to be used in funding the project, with Crown loans to cover the net requirements. This can be extended out to cover the maximum $\$ 494.194$ [million] in capital funding requirements, and paid off as the project begins to run surpluses in later years. ${ }^{48}$

As the plan continues to evolve, the housing for purchase is moving further and further out of reach of the community.

Initially, Porirua East was promised 2,000 Kiwibuild houses capped at \$550,000 that locals would have priority to purchase. The initial plan was still concerning for residents as the much-needed state-housing land is for sale. Concerns are increasing as the plan continues to change. The homes for purchase will now be a mix of affordable (no price range has yet been released) and market-priced homes. Recent valuations have shown a massive inflation in house prices across the city, with an increase of 62 percent in Waitangirua and Cannons Creek over the last three years. ${ }^{49}$

46 Elinor Chisholm, 'There goes the neighbourhood: a look at reducing state housing in communities,' One Two Three Home, 12 March 2014.

47 Philippa Howden-Chapman, Home Truths: Confronting New Zealand's Housing Crisis (Wellington: BWB, 2016), 79.

48 NZG, 'Eastern Porirua Regeneration Case,' 75.

49 Porirua City Council, 'New property values for Porirua released,' Porirua City, 16 December 2019, https://poriruacity.govt.nz/your-council/news/new-propertyvalues-porirua-released/ 
Alongside this increase there is the construction of a new link road called Transmission Gully that runs from Paraparaumu to Linden, which will be connected to Porirua. The new road is expected to take thousands more personal cars and will 'provide improved access [that] will lead to residential and business growth'. ${ }^{50}$ Combined with the rising property prices, Porirua East is a perfect storm for gentrification.

As well as guaranteeing affordable housing prices for current residents of the area, we need to ensure that the houses, whether private or stateowned, are built for purpose and not for profit. The trend is towards small, one- and two-bedroom homes that are usually two storeys. ${ }^{51}$ While there may be a need for these homes-for example, for re-housing formerly incarcerated people - there is also a need for much larger homes that are built for intergenerational living. State-housing communities like Porirua East are hubs for national and international communities, many of whom are finding home after displacement from their own homelands. It is common for there to be three or four generations living under one roof in the east, and for these to be places for whānau to stay when travelling through or as a base when moving from overseas. The answer is not to split everyone up; we need to build for the way people live.

\section{Truly accessible communities}

There is a significant opportunity with largescale-building developments like the one planned for Porirua East to improve accessibility for all its residents. However, Kāinga Ora has been developing a 'universal plan' for accessibility (currently unreleased) which, unfortunately, is universal not in that it caters for all but that it attempts to standardise housing for currently disabled people. It is narrowly focussed on disabilities related to mobility, with little consideration of visual or other disabilities. It also lacks a long-term understanding of people's changing needs and this is evident still in the preference for multi-storeyed apartments. By attempting to provide standardised housing for needs which

50 Porirua City Council, 'Transmission Gully', Porirua City, https://poriruacity. govt.nz/business/featured/transmission-gully/

51 NZG, 'Eastern Porirua Regeneration Case,' 17-18. 
are inherently variable and subject to change, the plan leaves unaddressed the myriad issues with current housing stock. ${ }^{52}$

People with disabilities should be involved with all design processes to ensure they can move around, use public transport, and visit friends and whānau independently. Houses, shops, footpaths, and public transport that is designed around the needs of our elderly, parents with young children, and people with disabilities are vital for ensuring the wellbeing of a diverse and vibrant community. A healthy community is one where all can participate in its activities.

\section{Adequate community engagement and representation}

There was no consultation prior to the development of the business case which secured government funds for the Porirua regeneration project. Since the announcement, consultation has been minimal and superficial. It is only when pressured by residents that employees of Kāinga Ora have publicly acknowledged that state housing and private rentals will be demolished for this development; however, this has not been acknowledged in writing. Moreover, in a meeting the public were excluded from in May 2019, Porirua City Council opted to make a request to the minister to use a streamlined planning process for the Porirua redevelopment. If this request is accepted, the decision-making power for land use and zoning will move from the council to the minister for the environment. Although the minister is responsible for initiating or utilising public consultation, there are no specific criteria that need to be met. This would severely limit public participation and public rights to appeal. HAP wrote to then Minister of Housing David Parker, outlining why the request should not be granted, and has presented a petition signed by residents of Porirua East to the council, demanding that the decision is reversed.

The composition of $\mathrm{Te}$ Pae-The Eastern Regeneration Advisory Board-has been another cause of concern for HAP. The purpose of the board is to ensure that the aims of the project are achieved and that

52 Te Ao Moana, 'Porirua - Ambitious project but some locals still worry,' te ao, 13 August 2019. 
the partners are held to account. Te Pae was established to provide the community a voice and, as such, it would seem logical for the community to elect its own representatives, but this is not the case. Initially, the plan was for each of the partners-Ngāti Toa Rangatira, the Council, and the Crown - to nominate its own representatives to the board. In response to community pushback, a council-led nomination process was initiated. Yet there is still no guarantee that any of those people will make it on to the board, as the partners are still responsible for deciding who will be appointed to it. ${ }^{53}$

Ultimately, there has been no real accountability to the communities of Porirua East shown within this development process. Any consultation which has been undertaken is superficial, vague, and at times culturally insensitive. The residents of Porirua East are, as residents, the best equipped to make knowledgeable and informed decisions about what effective development in the area would entail, yet they are consistently denied the opportunity to meaningfully shape the development process. We are the experts of our own lives and we will continue to advocate for community engagement in the redevelopment and for the accountability of the council and Kāinga Ora to the community.

\section{Protection of our natural and social environment}

The infrastructure in Porirua East is already inadequate. Heavy rain often leads to flooding and has recently led to a waste-water overflow. Significant investment is needed in the storm and waste-water systems; HAP is concerned that the $\$ 1.5$ billion allocated to the development will be insufficient as the business case does not factor in these costs. ${ }^{54}$ Throughout the consultation process, there has been no discussion of the recycling or disposal of houses and building materials. Hundreds of houses will be demolished, and care needs to be taken to minimise the waste generated

53 Porirua City Council, 'Te Pae - The Board,' Porirua City, https://poriruacity. govt.nz/your-council/city-planning-and-reporting/district-plan/responding-to-growth/ porirua-development/regeneration-board/

54 NZG, 'Eastern Porirua Regeneration Case.' 
through this process. The Porirua City Council needs to be vigilant when granting resource consents so as to ensure that developers have dust, run-off, and waste-control measures in place to protect our harbour and green spaces.

Transmission Gully and other road schemes begun by the previous National-led government are at odds with reducing the greenhouse-gas emissions that are causing global warming. Aotearoa New Zealand has one of the highest per-capita rates of greenhouse-gas emissions in the Annex I countries. ${ }^{55}$ The two largest contributors are dairy farming and road transport, particularly that generated by private commuters. Our high roadtransport emissions, which are also detrimental to the health of commuters and those who live near roads, reflects poor urban planning and poor publictransport services. ${ }^{56}$ The mistakes of the past are being repeated today by linking residential development to roading rather than public transport. Evidence from around the world shows that concentrating on new road schemes simply generates more car journeys; ultimately, new roads become just as congested as those they replace. ${ }^{57}$ Further, the spaces our elders have built for us and Ngāti Toa Rangatira tohu whenua and wāhi tapu need to be protected throughout the regeneration. The close proximity of the link road to Maraeroa Marae already shows a lack of respect and concern.

\section{Ensuring no whānau are pushed out}

Porirua East is a beautiful, diverse community with strong tagata o le moana communities, urban Māori, and working class Pākehā; more recently, we have welcomed new whānau from Syria, Myanmar, Columbia, and other countries. Some families, including Jasmine's children's family, has five generations living in Porirua East-it is where they have been born and raised, and where the bones of their tupuna rest. Churches, marae, mosques, community centres, and temples have been established through the hard

55 Ministry for the Environment, 'New Zealand's Greenhouse Gas Inventory 1990-2017,' Wellington, Ministry for the Environment, 2019.

56 Caroline Shaw et al, 'Health Consequences of Transport Patterns in New Zealand's Largest Cities,' The New Zealand Medical Journal 131, no. 1472 (2018): 64.

57 Howden-Chapman, Home Truths, 57. 
work of our elders so that our faith and cultures can continue to thrive. We have kōhanga reo, kura Māori, and tagata o le moana equivalents to ensure that our languages and tikanga are not lost. Porirua East is an important place for many people for many different reasons.

Similar regeneration projects have seen families, some of whom have lived in places like Glenn Innes and Pomare for many generations, moved to new areas and unable to return without significant agitation. ${ }^{58}$ While Kāinga Ora have their Choice to Return Policy, this was not upheld in Tāmaki and does not acknowledge the interdependence that communities have on each other: the deep relationships that people have built among themselves which reflect a lot of energy, care, and trust. Moving families out of their communities for even a short period can be detrimental to their physical, spiritual, and emotional wellbeing as it isolates children, single mothers, and the elderly from those networks of care. ${ }^{59}$ Members of HAP care for their grandparents, their mokopuna, and they are heavily involved in their communities. They are needed.

The Porirua regeneration project does not provide any protection for private tenants whose landlords will be encouraged to sell if their houses are in the middle of a superlot. This is particularly the case for people receiving the Income Related Rent Subsidy, a subsidy paid directly to private landlords. With insufficient numbers of state-owned rather than leased housing, tenants will be left to find new accommodation in a place that is under development, with rapidly increasing housing and rental prices. Private homeowners are also at risk, as the new Urban Development Bill, at select committee at the time of writing, empowers Kāinga Ora to acquire property for development. For most, the closest affordable places to live are towards Ōtaki and Levin, which are over an hour's drive away.

In short, the project has the potential to displace many families, some

58 Renee Gordons, Francis Collins and Robin Kearns, "It is the People That Have Made Glen Innes": State-led Gentrification and the Reconfiguration of Urban Life in Auckland,' International Journal of Urban and Regional Research 41, no. 5 (2017): 776.

59 Dayna Keene and Erin Ruel, “"Everyone Called Me Grandma”: Public Housing Demolition and Relocation Among Older Adults in Atlanta,' Cities: The International Journal of Urban Planning and Policy 35, no. 1 (2013): 359-364. 
of whom have already been pushed from their homelands due to the longstanding impacts of colonisation. The people who live here know the system intimately and have the solutions to its perpetual crisis; they just need the control and autonomy to enact those solutions.

\section{Te Tiriti o Waitangi and state housing}

Finally, we affirm that Housing Action Porirua is guided by te Tiriti o Waitangi and seek to uphold the mana and rangatiratanga of Ngāti Toa Rangatira in all our actions. We think that the government's attempt to bring Ngāti Toa Rangatira into the regeneration is a good gesture towards what an equitable relationship could look like. However, as we argued above, the city of Porirua in its entirety-including state housing - is not only built on stolen land, but built through stolen wealth and environmental desecration. This leads us to question whether the way the government seeks to partner with mana whenua is achieving a just, equitable, or mutual Tiriti-based relationship. Is the inclusion of Ngāti Toa Rangatira into the agreement sufficient, or is it a way for the government to claim that they have honoured their responsibilities while principally being concerned with legitimising their own project? Indeed, is te Tiriti about 'partnership' at all? No, it is not. It is about reaffirming the authority of tangata whenua over Aotearoa. The government's fixation on partnerships and consultation upholds parliamentary supremacy, subordinating te Tiriti to that.

To be clear, this is not a critique of Ngāti Toa Rangatira but of the Crown. The reality is that the 'Treaty' is instrumentalised to dispossess many peoples, taking the repatriation of land and power further out of reach of mana whenua, even though it appears more centrally in decision-making. While we do not have all the answers as to what should be done, it seems that such a regeneration project offers a timely opportunity to move toward the concrete reinstatement of the rangatiratanga of Ngāti Toa Rangatira. It could be part of a transfer of land and decision-making from Crown to hapu and iwi and a chance for the regeneration of the land, the sea, and the people. Clearly, something that partnerships into Crown projects-intended to hold 
onto power and multiply private wealth-will not do.

A fight for state housing, therefore, must also be a commitment to uphold tino rangatiratanga and mana motuhake. Regardless of the Crown's dishonour, te Tiriti o Waitangi yearns for positive transformation and likewise for regeneration. To realise that possibility, we need to hold on to a vision for what a Tiriti-based, re-indigenised society could be like. The foundation of this is addressing historical and ongoing dispossession and acknowledging that there can be no justice without a profound shift in power and resources back to tangata whenua. While models cannot easily be prescribed for this process, we must continue connecting our critiques of injustice and our visions of freedom to the restoration of tino rangatiratanga and mana motuhake.

\section{Conclusion}

The necessity for profit will always undermine the common good. This is exemplified by state housing, which has steadily been undermined by economic imperatives. Now, state-housing areas are supposedly 'concentrations of disadvantage', yet these places contain other, incalculable forms of wealth. They are communities that are home to deep ancestral knowledge and profound understandings of the world and our relationships in and with it. They are points of connection to ways of life that not only need to survive but are key to the survival of the earth.

What if state housing was our go-to model for renters? If anyone could rent them that would mean everyone would have a home within their price range. Everyone could have the same-no more subsidies for landlords and no more poverty and sickness due to expensive and unhealthy homes. People would have money left over to participate in society or to save for a deposit for a house. In light of intense economic and social crises, the expansion of public, regulated housing is one of the most vital political demands of our time. As we have argued, it is vital precisely because it encapsulates all aspects of social life and much about how we relate to the earth.

State housing is not the evil it is made out to be by those who sell, as 
well as those who buy into, the idea that a home is a commodity. It is also not a service reserved for the deprived. It is a central part of our community wellbeing, and Housing Action Porirua will continue to fight to protect the communities that have made state houses their home, and welcome solidarity in that struggle. We will continue to struggle for the possibility of a home for all people, guided by the understanding that this does not have to be achieved through dispossessing and displacing others. We can only find homes for all when we honour te Tiriti and commit to building and rebuilding forms of social organisation where people's lives are valued more than the structures they live in. 